\title{
Prevention of Labour-Associated Pelvic Floor Injuries - What is Known for Sure
}

\author{
Prävention geburtsbedingter Beckenbodenschädigung - Was ist gesichert?
}

Authors

Affiliations
H. B. G. Franz ${ }^{1}$, C. Erxleben ${ }^{2}$, A. Franz ${ }^{2}$, R. Hofmann ${ }^{1}$

${ }^{1}$ Klinik für Gynäkologie und Geburtshilfe, Klinikum Braunschweig, Braunschweig

${ }^{2}$ Charite - Universitätsmedizin, Berlin

\section{Key words}

- pelvic floor injuries

- delivery method

- incontinence

- genital prolapse

Schlüsselwörter

- Beckenbodenschädigung

- Entbindungsmodus

- Inkontinenz

- Genitalprolaps

\section{Abstract \\ $\nabla$}

In order to avoid pelvic floor injuries a caesarean section is on the one hand often requested by the pregnant women and, on the other hand, offered by obstetric staff. For both forms of delivery, comprehensive risk-benefit analyses should be carried out before deciding in favour of the surgical procedure. The present brief review summarizes the current evidence on the avoidance of pelvic floor injuries.

\section{Introduction}

In a report published in October 2011 by Handa et al. [1] on confirmed pelvic floor disorders 5-10 years after vaginal delivery or, respectively, caesarean section, the authors came to the conclusion that there was a significant relationship between spontaneous vaginal delivery and stress urethral incontinence and genital prolapse (POP), and that this was much more dramatic in cases of surgical vaginal delivery [2,3]. In an editorial [4] on this subject the renowned urogynecologist Ingrid Nygaard (University of Utah School of Medicine) posed the somewhat provocative thesis: Vaginal Birth - A Relic of the Past in Bulldogs and Women? Her résumé at the end of the editorial as a recommendation for routine delivery by caesarean section in order to reduce labour-associated pelvic floor trauma is, according to our present state of knowledge, ill-advised.

What then are the consequences of pregnancy and birth on the pelvic floor and its function and are there any preventative measures to avoid pelvic floor disorders that can be recommended on the basis of the current state of data?

\section{Zusammenfassung \\ $\nabla$}

Zur Vermeidung einer Beckenbodenschädigung wird die Sectio caesarea zum einen von Schwangeren eingefordert, zum anderen aber auch von Geburtshelfern angeboten. Für beide Entbindungsmodi sind die Risiken vs. die Vorteile abzuwägen, bevor die operative Entbindung favorisiert wird. Diese Kurzübersicht zeigt die derzeitige Evidenz auf, eine geburtsbedingte Beckenbodenschädigung zu vermeiden.

\section{Einleitung \\ $\nabla$}

In einer im Oktober 2011 erschienenen Publikation von Handa et al. [1] über nachweisbare Beckenbodenstörungen 5-10 Jahre nach vaginaler bzw. Kaiserschnittgeburt kommen die Autoren zu dem Ergebnis, dass ein signifikanter Zusammenhang zwischen vaginaler Spontangeburt und urethraler Belastungsinkontinenz und Genitalprolaps (POP) besteht, und dieser noch viel dramatischer ausfällt, wenn die Entbindung vaginal-operativ durchgeführt wurde $[2,3]$. In dem dazu erschienenen Editorial [4] stellt die ausgewiesene Urogynäkologin Ingrid Nygaard (University of Utah School of Medicine) die etwas provozierende Frage: Vaginal Birth - A Relic of the Past in Bulldogs and Women? Ihr Resümee am Ende des Editorials: eine routinemäßige Empfehlung einer Kaiserschnittenbindung zur Reduzierung des geburtsbedingten Beckenbodentraumas sei bei unserem derzeitigen Wissensstand ill-advised.

Welche Auswirkungen haben nun Schwangerschaft und Geburt auf den Beckenboden und seine Funktionen, und gibt es präventive Maßnahmen zur Vermeidung von Beckenbodenstörungen, die auf Grundlage der derzeitigen Datenlage zu empfehlen sind?
Dr. Heiko B. G. Franz, PD

Klinikum Braunschweig

Klinik für Gynäkologie

und Geburtshilfe

Celler Straße 38

38114 Braunschweig

h.franz@

klinikum-braunschweig.de 


\section{Pelvic Floor Disorders after Pregnancy and Birth} $\nabla$

Pelvic floor disorders (PFD) occur sporadically in women or in combination in the form of stress urinary incontinence (SUI), anal incontinence (fecal and/or flatulence incontinence) and pelvic organ prolapse (POP).

It has been demonstrated in numerous publications [5-7] that women with at least one birth in their history exhibit a higher incidence of PFD. Handa et al. [1] found in their patients that, in relation to caesarean section, 8.9 spontaneous vaginal births led to an additional POP case.

The influence of delivery mode on the development of a PFD was also particularly clearly demonstrated in the Evanston-Northwestern Twin Sisters Study and a direct twins comparison between nulliparous and parous women showed a 3- to 4-fold higher risk to develop a PFD for the parous women [8].

For the symptom of stress urethral incontinence (SUI) after pregnancy and delivery not only the mode of delivery but also the negative influence of pregnancy on the integrity of the pelvic floor must be considered as risk factors. During pregnancy tissue compression and (over)extension and on vaginal delivery tissue (over)extension through to rupture of the musculature, connective tissue and nerve fibres are seen as the mechanisms of pelvic floor damage [9].

From the extensive literature on SUI and the mode of delivery we mention here a recent study from the Karolinska University in Stockholm, Sweden. In a large cohort study Leijonhufvud et al. [10] investigated the risk for stress urethral incontinence and prolapse surgery in relation to the mode of delivery ( Table $\mathbf{1}$ ). It was demonstrated thereby that women who had only vaginal deliveries had a significantly higher risk not only for an SUI but also for the necessity of a prolapse operation during later life in comparison to women who had only caesarean deliveries.

In addition, studies have shown that the onset of an SUI during pregnancy and its continuation for 3 months after delivery is a significant risk factor for an SUI in later life. In their study Viktrup et al. [11] demonstrated that $91 \%$ of the primiparous women who exhibited a urethral incontinence at 3 months after delivery, had an SUI 12 years later. If the first delivery was by caesarean section the risk for an SUI was significantly lower ( $\mathrm{p} \leq 0.04)$. McArthur et al. [12] came to a similar conclusion with a prevalence of $75 \%$ after 6 years.

The first vaginal delivery seems to be particularly relevant with respect to the integrity of the pelvic floor. Thus, Sultan et al. [13] showed that in $35 \%$ of the primiparous women and $44 \%$ of the multiparous women, anal sphincter defects were detectable by ultrasound. Vaginal surgical deliveries are thereby usually associated with a higher risk of anal sphincter injuries [14,15]. Numerous other studies have confirmed the highly traumatic effects of the first vaginal birth also in regard to other muscular compo-

Table 1 Risk for stress urethral incontinence and prolapse operation in relation to mode of delivery [10].

\begin{tabular}{|c|c|}
\hline \multicolumn{2}{|c|}{ In total $\mathrm{n}=96396$ patients } \\
\hline \multicolumn{2}{|c|}{ Vaginal delivery only vs. caesarean section only } \\
\hline ( $n=63229$ patients) & ( $\mathrm{n}=33167$ patients) \\
\hline Stress incontinence: & HR $2.9(95 \% \mathrm{Cl} 2.4-3.6)$ \\
\hline POP: & HR $9.2(95 \% \mathrm{Cl} 7.0-12.1)$ \\
\hline
\end{tabular}

\section{Beckenbodenstörungen \\ nach Schwangerschaft und Geburt \\ $\nabla$}

Beckenbodenstörungen (pelvic floor disorders, PFD) treten bei der Frau einzeln oder in Kombination in Form der urethralen Belastungsinkontinenz (stress urinary incontinence, SUI), der analen Inkontinenz (Stuhl- und/oder Flatusinkontinenz) und des Genitalprolapses (pelvic organ prolapse, POP) auf.

In zahlreichen Publikationen [5-7] wurde nachgewiesen, dass bei Frauen mit mindestens einer Geburt in der Anamnese die PFD eine höhere Prävalenz zeigt. Handa et al. [1] zeigten in ihrer Untersuchung, dass in Relation zur Sectio caesarea 8,9 vaginale Spontangeburten zu einem zusätzlichen POP-Fall führen.

Der Einfluss einer Geburt auf die Entwicklung einer PFD ließ sich insbesondere auch in der Evanston-Northwestern Twin Sisters Study nachweisen und führte beim direkten Zwillingsvergleich Nulliparität vs. Parität zu einem 3- bis 4-mal höheren Risiko bei Parität, eine PFD zu entwickeln [8].

Für das Symptom der urethralen Belastungsinkontinenz (SUI) nach Schwangerschaft und Geburt müssen als Risikofaktoren sowohl der Geburtsmodus als auch der negative Einfluss der Schwangerschaft an sich auf die Integrität des Beckenbodens betrachtet werden. Als Mechanismen der Beckenbodenschädigung werden während der Schwangerschaft Gewebekompression und (-über)-dehnung und bei der vaginalen Geburt die Gewebe(über)dehnung bis hin zur Ruptur bei Muskulatur, Bindegewebe und Nervenfasern angesehen [9].

Aus der umfangreich vorhandenen Literatur zur SUI und dem Entbindungsmodus sei hier besonders auf eine neuere Studie von der Karolinska Universität in Stockholm, Schweden, verwiesen. In einer großen Kohortenstudie haben Leijonhufvud et al. [10] das Risiko für eine urethrale Belastungsinkontinenz und Prolapschirurgie in Relation zum Entbindungmodus untersucht ( $\odot$ Tab. 1 ). Dabei wurde nachgewiesen, dass Frauen, die nur vaginal entbunden hatten, im Vergleich zu Frauen, die nur per sectionem entbunden wurden, ein signifikant erhöhtes Risiko sowohl für eine SUI als auch für die Notwendigkeit einer Deszensusoperation im weiteren Leben hatten.

Studien konnten außerdem zeigen, dass ein Beginn einer SUI während der Schwangerschaft und ihr Fortbestehen 3 Monate nach der Entbindung signifikante Risikofaktoren für eine SUI in späteren Lebensabschnitten sind. In einer Untersuchung von Viktrup et al. [11] zeigten $91 \%$ der Primiparae, die 3 Monate nach der Entbindung eine urethrale Inkontinenz aufwiesen, 12 Jahre später eine SUI. Erfolgte die erste Geburt per sectionem, war das Risiko für eine SUI signifikant niedriger $(\mathrm{p} \leq 0,04)$. Zu einem ähnlichen Ergebnis kamen McArthur et al. [12] mit einer Prävalenz von 75\% nach 6 Jahren.

Die erste vaginale Entbindung scheint besonders verhängnisvoll für die Integrität des Beckenbodens. So zeigten Sultan et al. [13], dass bei 35\% der Primiparae und 44\% der Multiparae 6 Wochen postpartal sonografisch anale Sphinkterdefekte nachweisbar waren. Vaginaloperative Entbindungen sind dabei gewöhnlich mit einem höheren Risiko für anale Sphinkterverletzungen belastet [14,15]. Zahlreiche weitere Studien bestätigten die stark traumatisierenden Auswirkungen einer ersten vaginalen Geburt, auch in Hinblick auf andere muskuläre Komponeten wie z. B. dem M. levator ani $[16,17]$. Valsky et al. [18] berechneten Cut-off-Werte für das Risiko einer Verletzung des M. levator ani: 1 . Bei einem fetalen Kopfumfang $\geq 35 \mathrm{~cm}$ verdoppelt sich das Risiko und es steigt bei einem Wert von $\geq 35,5 \mathrm{~cm}$ auf 3,5 an; 2. bei einer Austreibungsperiode bis 90 Minuten verdoppelt sich das Risiko und es steigt bei einer Dauer von > 160 Minuten auf 3,55 an. 
nents such as, e.g., the levator ani muscles [16,17]. Valsky et al. [18] calculated cut-off values for the risk of a levator ani muscle injury: firstly at a fetal head circumference $\geq 35$ the risk is doubled and increases further to a value of 3.5 at a circumference $\geq 35.5 \mathrm{~cm}$; secondly with a expulsive stage of 90 minutes the risk is doubled and increases to 3.55 at a duration of $>160$ minutes.

\section{Preventative Measures}

Prophylactic training of the pelvic floor musculature, antenatal perineal massage, choice of delivery position and regional anesthesia of the pelvic floor do not reduce the risk to develop a PFD [19]. The value of an elective caesarean section as a preventative measure to avoid a PFD is the topic of controversial discussion, especially as at present only observational studies but no randomized controlled studies are available [20,21].

With regard to SUI and anal incontinence, the advantages of the caesarean section are rather limited ( Table 2). In the Term Breech Trial, irrespective of whether primarily a vaginal delivery mode or an elective caesarean section was planned, 2 years after delivery SUI (planned caesarean $17.8 \%$ vs. planned vaginal delivery $21.8 \%$ ), fecal incontinence ( 2.4 vs. $2.2 \%$ ) and flatulence incontinence (13.1 vs. $11.5 \%$ ) were observed in approximately equal numbers in both groups [18]. The Childbirth and Pelvic Symptoms (CAPS) Study came to a similar conclusion 6 months after vaginal delivery or, respectively, caesarean section [21]. Anal incontinence symptoms were observed not only after elective but also after secondary caesarean sections [22]. In a systematic review, Nelson et al. [23] examined the efficiency of a caesarean section with regard to the maintenance of anal continence in 3010 caesarean and 11440 vaginal deliveries. After a caesarean section the relative risk for fecal incontinence was 0.91 (95\% confidence interval [CI] 0.74-1.14) and for a flatulence incontinence 0.98 (95\% CI 0.86-1.13). In order to avoid just one case of fecal incontinence, 167 caesarean sections would have to be performed.

\section{Secondary Prevention}

How are those pregnant women to be advised with regard to the mode of delivery when they have already suffered from a PFD in the course of a previous pregnancy and labour and possibly also have already had to undergo a prolapse and/or an incontinence operation?

This is also a topic of controversial discussion.

In a summary of the State-of-the-Science Conference 2006 sponsored by the National Institutes of Health $(\mathrm{NIH})$ on the topic: Cesarean Delivery on Maternal Request, A.M. Weber [24] reported that, on the one hand, some clinicians recommend caesarean section to all women after anal sphincter injury while, on the other hand, others recommend it only when the case history includes anal incontinence. Ultimately, however, there is no evidence either for a liberal or for a restrictive use of caesarean section after anal sphincter injury. Nevertheless in this context, among others, we refer to the work of Faltin et al. [25] and Mahony et al. [26] showing that a renewed vaginal delivery with a preexisting sonographically confirmed anal sphincter defect has a relative risk of $11.2(95 \% \mathrm{CI} 1.4-86.2)$ for anal incontinence and that in $26 \%$ of the cases a marked deterioration of the anal incontinence can be observed. The algorithm developed by Sultan et al.
Table 2 Limited preventative advantages of elective caesarean section for the development of postpartum urinary incontinence [19].

\begin{tabular}{|c|c|}
\hline \multicolumn{2}{|l|}{ Term Breech Trial } \\
\hline \multicolumn{2}{|c|}{ Examination time point: 3 months post partum } \\
\hline \multirow[t]{3}{*}{ Urinary incontinence } & caesarean section $4.5 \%$ \\
\hline & vaginal delivery $7.3 \%$ \\
\hline & OR $0.62 ; 95 \% \mathrm{Cl} 0.41-0.93$ \\
\hline
\end{tabular}

Compensated effect after 2 years

\section{Präventive Maßnahmen}

$\nabla$

Prophylaktisches Training der Beckenbodenmuskulatur, antenatale Dammmassage, Wahl der Entbindungsposition und Regionalanästhesie des Beckenbodens mindern nicht das Risiko eine PFD zu entwickeln [19].

Der Stellenwert einer elektiven Sectio caesarea als Präventivmaßnahme zur Vermeidung einer PFD wird kontrovers diskutiert, zumal keine kontrolliert randomisierten Studien, sondern derzeitig nur Beobachtungsstudien vorhanden sind [20,21].

In Bezug auf eine SUI und eine anale Inkontinenz sind die Vorteile eines Kaiserschnitts eher limitiert ( Tab. 2). In dem Term Breech Trial konnte, unabhängig davon, ob primär ein vaginaler Entbindungsmodus oder eine elektive Sectio geplant war, 2 Jahre nach Entbindung eine SUI (geplante Sectio $17,8 \%$ vs. geplante vaginale Geburt $21,8 \%$ ), eine Stuhl- (2,4 vs. $2,2 \%$ ) und eine Flatusinkontinenz $(13,1$ vs. $11,5 \%$ ) in annähernd derselben Höhe in beiden Gruppen beobachtet werden [18]. Zu demselben Ergebnis kam auch die Childbirth and Pelvic Symptoms (CAPS) Study 6 Monate nach vaginaler Geburt bzw. nach Sectioentbindung [21]. Anale Inkontinenzsymptome werden sowohl nach einer elektiven als auch nach einer sekundären Kaiserschnittentbindung beobachtet [22]. Nelson et al. [23] haben in einem systematischen Review die Effizienz einer Sectio caesarea in Bezug auf den Erhalt der analen Kontinenz bei 3010 Sectiones und 11440 vaginalen Entbindungen untersucht. Nach einer Sectio lag das relative Risiko für eine Stuhlinkontinenz bei 0,91 (95\%-Konfidenzintervall [KI] 0,74-1,14) und für eine Flatusinkontinenz bei 0,98 (95\%-KI 0,861,13). Um einen Fall einer Stuhlinkontinenz zu vermeiden, müssten 167 Sectiones durchgeführt werden.

\section{Sekundäre Prävention}

$\nabla$

Wie sind schwangere Frauen bez. des zu wählenden Entbindungsmodus zu beraten, die bereits durch eine vorangegangene Entbindung eine PFD erlitten haben und ggf. bereits eine Deszensus- und/ oder Inkontinenzoperation haben durchführen lassen müssen? Auch hier wird die Diskussion kontrovers geführt.

A.M. Weber [24] berichtet in ihrer Zusammenfassung von der von den National Institutes of Health (NIH) gesponserten State-of-theScience Conference 2006 mit dem Thema: Cesarean Delivery on Maternal Request, dass einerseits einige Kliniker nach einer analen Sphinkterverletzung allen Frauen die Kaiserschnittentbindung empfehlen, anderseits andere Kliniker nur bei vorbestehender anamnestischer analer Inkontinenz dazu raten. Letztlich gäbe es jedoch keine Evidenz für einen liberalen oder restriktiven Einsatz der Sectio nach einer analen Sphinkterverletzung. Nichtsdestotrotz sei in diesem Zusammenhang u.a. auf die Arbeiten von Faltin et al. [25] und Mahony et al. [26] verwiesen, die zeigten, dass eine erneute vaginale Entbindung bei bestehendem sonografischen analen Sphinkterdefekt ein relatives Risiko von 11,2 (95\%-KI 1,4-86,2) für eine anale Inkontinenz 


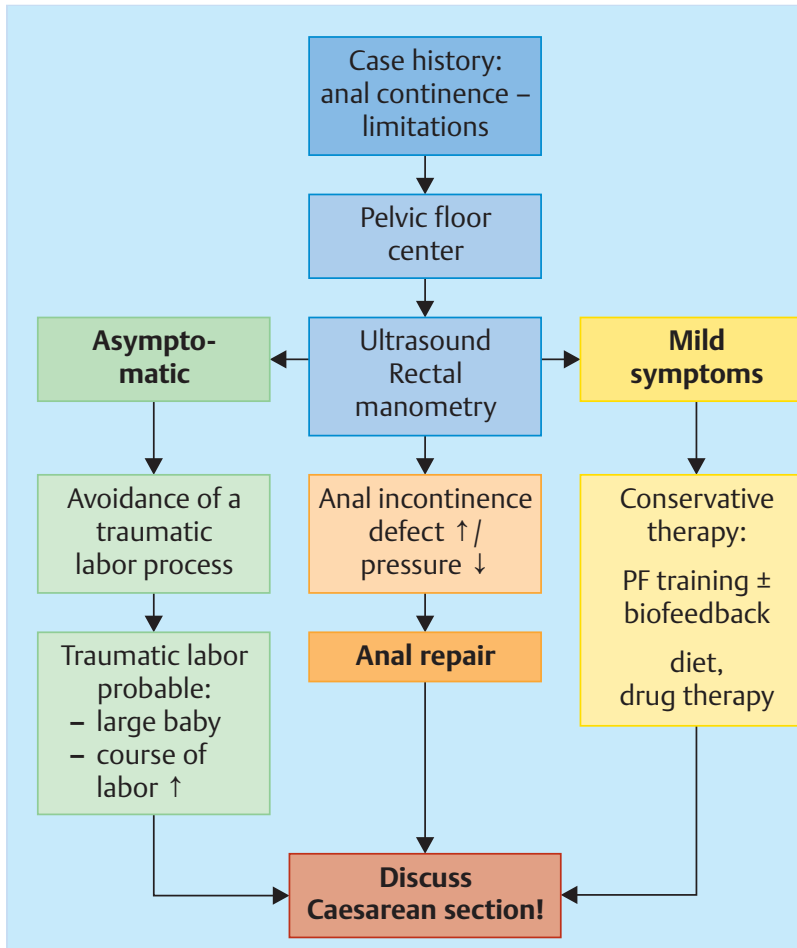

Fig. 1 Treatment algorithm for women with anal incontinence in their case history and a renewed pregnancy, adapted from Sultan et al. [27].

[27] ( Fig. 1) provides an aid for counseling pregnant women with a case history of anal incontinence and/or labour-related sphincter damage.

The systematic review of the Cochrane Database [28] and current randomized studies $[29,30]$ show that pelvic floor training can have a positive effect with regard to the avoidance of urinary incontinence in advanced pregnancy and post partum as well as the avoidance of postpartum anal incontinence. An intensified training program with physiotherapeutic support seems to be advantageous $[28,29]$.

The popular use of TVT as well as that of other alloplastic materials (mesh) in incontinence and prolapse surgery has led to these surgical methods being increasingly used in women of childbearing age. Thus, it is not surprising that the incidence of pregnancies subsequent to incontinence/prolapse operations is increasing [31-33]. In this situation also it appears that caesarean section no longer represents the exclusive mode of delivery, albeit with a still very small number of case observations [34,35].

\section{Conclusion}

Primiparity, vaginal surgical delivery, large fetal head circumference and a prolonged expulsive stage are risk factors for a labourassociated pelvic floor injury. A caesarean section reduces the risk for pelvic floor injury but does not completely prevent it. At present those patients with a particularly high risk profile for a labour-associated pelvic floor injury cannot be identified unambiguously. In the case of an already known, labour-associated pelvic floor injury, extended and especially imaging diagnostics should be performed and the results discussed in consultations with the pregnant patient just in the context of a possible deteri- aufweist und dass in 26\% der Fälle eine deutliche Verschlechterung der analen Kontinenzleistung zu beobachten ist. Eine Hilfestellung bei der Beratung der schwangeren Patientin mit anamnestischer analer Inkontinenz und/oder geburtsbedingtem Sphinkterschaden bildet der von Sultan et al. [27] entwickelte Algorithmus ( $\square$ Abb. 1).

Der systematische Review der Cochrane Database [28] und aktuelle randomisierte Studien $[29,30]$ zeigen, dass Beckenbodentraining einen positiven Effekt in Hinblick auf die Vermeidung einer Harninkontinenz in der fortgeschrittenen Schwangerschaft und postpartal sowie die Vermeidung einer postpartalen analen Inkontinenz haben kann. Ein intensiviertes Trainingsprogramm mit physiotherapeutischer Unterstützung scheint dabei von Vorteil zu sein $[28,29]$.

Der populäre Einsatz des TVT, aber auch anderer alloplastischer Materialien (Netze) in der Inkontinenz- und Deszensuschirurgie, hat dazu geführt, dass diese operativen Methoden auch zunehmend bei Frauen im noch reproduktiven Lebensalter eingesetzt werden. Deshalb ist es nicht verwunderlich, dass die Inzidenz einer Schwangerschaft nach durchgeführter Inkontinenz-/Deszensusoperation zunimmt [31-33]. Auch hier scheint, bei jedoch insgesamt noch sehr geringen Fallbeobachtungen, nicht mehr die Sectio ceasarea den ausschließlichen Entbindungsmodus darzustellen [34,35].

\section{Fazit}

Primiparität, vaginaloperative Entbindungen, großer fetaler Kopfumfang und eine verlängerte Austreibungsperiode sind Risikofaktoren für eine geburtsassoziierte Beckenbodenschädigung. Der Kaiserschnitt reduziert das Risiko für eine Beckenbodenschädigung, ist aber nicht vollständig präventiv. Derzeitig lassen sich die Patientinnen, die ein besonders hohes Risikoprofil für eine geburtsbedingte Beckenbodenschädigung haben, noch nicht eindeutig identifizieren. Bei bereits bekannter geburtsbedingter Beckenbodenschädigung sollte eine erweiterte, insbesondere bildgebende Diagnostik durchgeführt werden und die Ergebnisse in dem Beratungsgespräch mit der Schwangeren gerade in Hinblick auf eine mögliche Verschlechterung der Beckenbodenfunktion durch eine (weitere) vaginale Geburt diskutiert werden (๑ Tab. 3).

\section{Interessenkonflikt}

\section{$\nabla$}

Es bestehen keine Interessenkonflikte.

oration of the pelvic floor function as the consequence of a (further) vaginal delivery ( Table 3 ).

\section{Conflict of Interest}

\section{$\nabla$}

The authors declare no conflicts of interest.

Table 3 Relative risk for fecal and flatulence incontinence after a caesarean section [23].

\begin{tabular}{|c|c|}
\hline \multicolumn{2}{|l|}{ Systematic Review } \\
\hline \multicolumn{2}{|c|}{ (3010 caesarean sections vs. 11440 vaginal deliveries) } \\
\hline After caesarean section: & \\
\hline Fecal incontinence & RR 0.91; 95\% Cl 0.74-1.14 \\
\hline Flatulence incontinence & RR 0.98; 95\% Cl 0.86-1.13 \\
\hline
\end{tabular}




\section{References}

1 Handa V, Blomquist J, Knoepp L et al. Pelvic floor disorders 5-10 years after vaginal or cesarean childbirth. Obstet Gynecol 2011; 118: 777784

2 Beckmann MW, Bader W, Bechtold I et al. Finanzierung und finanzielle Probleme von Leistungen und Strukturen im Fachgebiet Gynäkologie und Geburtshilfe im Jahr 2011 - allgemeine Aspekte und geburtshilfliche Versorgung. Geburtsh Frauenheilk 2011; 71: 367-380

3 Beckmann MW, Bader W, Bechtold I. Finanzierung und finanzielle Probleme von Leistungen und Strukturen im Fachgebiet Gynäkologie und Geburtshilfe im Jahr 2011 - DRG-System und stationäre Versorgung inklusive Urogynäkologie und benigner wie auch maligner gynäkologischer Operationen. Geburtsh Frauenheilk 2011; 71: 497-510

4 Nygaard I. Vaginal birth: A relic of the past in bulldogs and women? Obstet Gynecol 2011; 118: 774-776

5 Turner CE, Young JM, Solomon MJ et al. Incidence and etiology of pelvic floor dysfunction and mode of delivery: an overview. Dis Colon Rectum 2009; 52: 1186-1195

6 Hendrix SL, Clark A, Nygaard I et al. Pelvic organ prolapse in the Women's Health Initiative: gravity and gravidity. Am J Obstet Gynecol 2002; 186: 1160-1166

7 Rortveit G, Hannestad YS, Daltveit AK et al. Age- and type-dependent effects of parity on urinary incontinence: the Norwegian EPINCONT study. Obstet Gynecol 2001; 98: 1004-1010

8 Abramov Y, Sand PK, Botros SM et al. Risk factors for female anal incontinence: new insight through the Evanston-Northwestern Twin Sisters Study. Am J Obstet Gynecol 2005; 106: 726-732

9 Handa $V$. Pelvic floor disorders associated with pregnancy and childbirth (2012). Im Internet: www.uptodate.com; Stand: 24.04 .2012

10 Leijonhufvud A, Lundholm C, Cnattingius $S$ et al. Risk of stress urinary incontinence and pelvic organ prolapse surgery in relation to mode of childbirth. Am J Obstet Gynecol 2011; 204: 70.e1-70.e6

11 Viktrup L, Rortveit G, Lose G. Risk of urinary incontinence twelve years after the first pregnancy and delivery. Obstet Gynecol 2006; 108: 248254

12 MacArthur C, Glazener CM, Wilson PD et al. Persistent urinary incontinence and delivery mode history: a six-year longitudinal study. BJOG 2006; 113: 218-224

13 Sultan AH, Kamm MA, Hudson CN et al. Anal-sphincter disruption during vaginal delivery. N Engl J Med 1993; 329: 1905-1911

14 Eason $E$, Labreque $M$, Wells $G$ et al. Preventing perineal trauma during childbirth: a systematic review. Obstet Gynecol 2000; 95: 464-471

15 Wheeler II T, Richter H. Delivery method, anal sphincter tears and fecal incontinence: new information on a persistent problem. Curr Opin Obstet Gynecol 2007; 19: 474-479

16 Schwertner-Tiepelmann N, Thakar R, Sultan AH et al. Obstetric levator ani muscle injuries: current status. Ultrasound Obstet Gynecol 2012; 39: $372-383$

17 Dietz HP. Geburtsbedingtes Beckenbodentrauma. Geburtsh Frauenheilk 2010; 70: 969-978

18 Valsky DV, Messing B, Pomp R et al. Fetal head circumference and length of second stage of labor are risk factors for levator ani muscle injury, diagnosed by 3-dimensional transperineal ultrasound in primiparous women. Am J Obstet Gynecol 2009; 201: 91.e1-91.e7
19 Lavy Y, Sand P, Kaniel C et al. Can pelvic floor injury secondary to delivery be prevented? Int Urogynecol J 2012; 23: 165-173

20 Hannah ME, Whyte H, Hannah WJ et al. Maternal outcomes at 2 years after planned cesarean section versus planned vaginal birth for breech presentation at term: the International Randomized term Breech Trial. Am J Obstet Gynecol 2004; 191: 917-927

21 Borello-France D, Bugio KL, Richter HE et al.; Pelvic floor Disorders Network. Prevalence of fecal and urinary incontinence after childbirth: the Childbirth and Pelvic Symptoms (CAPS) Study. Obstet Gynecol 2006; 108: 863-872

22 Lal M, Mann CH, Callender $R$ et al. Does cesarean delivery prevent anal incontinence? Obstet Gynecol 2003; 101: 305-312

23 Nelson R, Westercamp M, Furner S. A systematic review of the efficacy of cesarean section in the preservation of anal continence. Dis Colon Rectum 2006; 49: 1587-1595

24 Weber AM. Elective cesarean delivery: the pelvic perspective. Clin Obstet Gynecol 2007; 50: 510-517

25 Faltin DL, Sangalli MR, Roche B et al. Does a second delivery increase the risk of anal incontinence. Br J Obstet Gynecol 2001; 108: 684-688

26 Mahony R, Behan M, O'Connell PR et al. Effect of second vaginal delivery on anal function in patients at risk of occult anal sphincter injury after first forceps delivery. Dis Colon Rectum 2008; 51:1361-1366

27 Sultan AH, Thakar R, Fenner D. Perineal and anal Sphincter Trauma. London: Springer; 2007

28 Hay-Smith J, Mørkved S, Fairbrother KA et al. Pelvic floor muscle training for prevention and treatment of urinary and faecal incontinence in antenatal and postnatal women. Cochrane Database Syst Rev 2008; 4: CD007471

29 Stafne S, Salvesen K, Romundstad $P$ et al. Does regular exercise including pelvic floor muscle training prevent urinary and anal incontinence during pregnancy? A randomized controlled trial. BJOG 2012; DOI: $10.1111 / \mathrm{j} .1471-0528.2012 .03426 . x$

30 Mason $L$, Roe B, Wong $\mathrm{H}$ et al. The role of antenatal pelvic floor muscle exercises in prevention of postpartum stress incontinence: a randomized trial. J Clin Nurs 2010; 19: 2777-2786

31 Taran-Munteanu L, Taran FA, Hosang B et al. Abdominale Sakrokolpopexie versus vaginale sakrospinale Fixation: klinische Parameter und subjektive Patienteneinschätzungen. Geburtsh Frauenheilk 2011; 71: 760-766

32 Kemp B, Maass N, Najjari L et al. Magnetstimulation - eine zusätzliche Therapieoption beim OAB-Syndrom. Geburtsh Frauenheilk 2010; 70: 580-583

33 Naumann G, Kölbl H. Current developments and perspectives on the diagnosis and treatment of urinary incontinence and genital prolapse in women. Geburtsh Frauenheilk 2012; 72: 202-210

34 Gadonneix P, Campagna G, Villet R. Pregnancy after laparoscopic sacral colpopexy - a case report. Int Urogynecol J 2012; 23: 651-653

35 Kohorst F, Flock F, Kreienberg $R$ et al. Pregnancy and delivery after tension-free vaginal tape (TVT) procedure: literature review and case report. Eur J Obstet Gynecol Reprod Biol 2010; 151: 10-13

Deutschsprachige Zusatzinformationen online abrufbar unter: www.thieme-connect.de/ejournals/toc/gebfra. 